\section{Variations in the Level of Lake George, Australia.}

ON May I8, I876, a letter appeared in NATURF from Canon $R$. Abbay on the subject of the changes in level of Lake George, in the south-east of New South Wales, which in the past hundred years has varied from a small swamp to a depth of 25 feet or more. We have now received from Cahon Abbay a letter and a diagram showing the variations of level in the lake from 1817 to 1918 . The latter, which is reproduced in Fig. $\mathrm{I}$, was drawn from information compiled by the late Mr. H. C. Russell, Government Astronomer of New South Wales, up to I904, and since that date by the Commonwealth Meteorological Bureau. It also shows the " residual rainfall curves" for Goulburn, the nearest station, and for Sydney, $15^{\circ}$ miles distant. A residual rainfall curve is obtained by finding the difference of rainfall for each year from the average for the whole period and adding up the differences for successive years, so that the figure plotted for any year represents the total excess or deficit of rainfall from the beginning of observations until that year. The curves show, as Canon Abbay points out, that while rainfall is
$\mathrm{L}$ (Actual level, inches from base) $=0.36 \mathrm{R}+0.36 \mathrm{~S}$.

The years in which the lake was dry have been omitted trom the calculations. The results confirm those obtained from Lake Victoria, that variations of evaporation are probably more important than rainfall variations in determining the level of lakes, and that the rate of evaporation is appreciably greater when sunspots are few than when they are numerous.

The diagram shows that the rairfall at Goulburn agrees fairly closely with that at Sydney, but if the rainfall at several stations over the lake basin had been available for a long period, there is no doubt that the correlation with their average would have been appreciably higher than that with Sydney rainfall. It also appears that the evaporation at Lake George is not determined by sunspots to the same extent as that at Lake Victoria. As Canon Abbay points out, the frequency of west and north-west winds would be of great importance in this connexion, and this would be governed by the pressure gradient between, say, Melbourne and Brisbane.

In 1875 Canon Abbay thought that the rise in the lake, which had proceeded fairly steadily from about I849 until that date, was connected with the destruction of "bush," allowing the rainfall to run

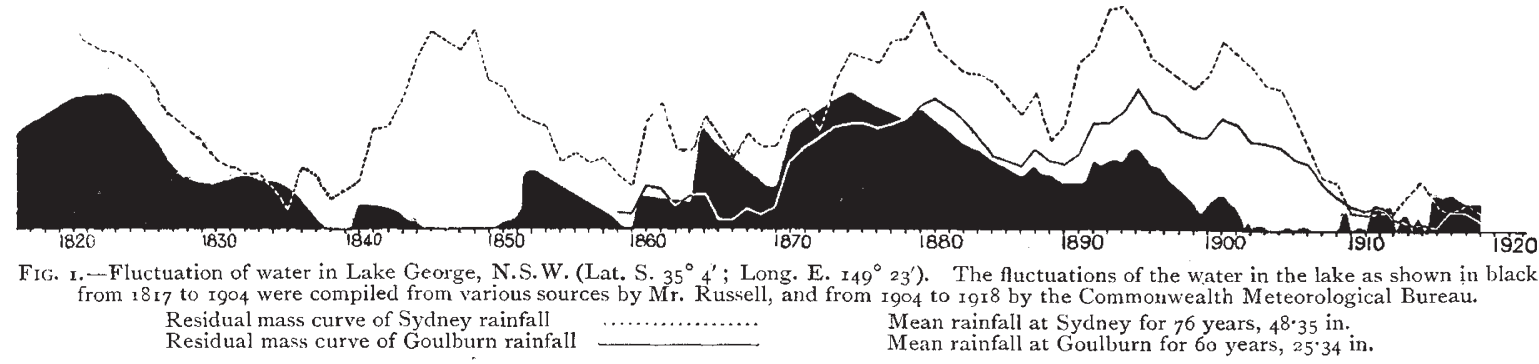

evidently an important factor in the level of the lake, there must also be other influences at work.

The lake is without outlet, and we may accordingly regard its changes of level as determined by the balance between the rainfall and evaporation in its basin, the loss by seepage probably being negligible. As a measure of rainfall the long series of observations at Sydney has been employed from the commencement of the official observations in 1840 . The question of evaporation is more difficult, but it has recently been found that in the Central African lakes, Victoria and Albert, the amount of evaporation bears a very close inverse relationship to the number of sunspots, the correlation coefficient between lake level (Lake Victoria) and sunspot number, after elimination of rainfall, being as high as +0.90 , and much higher than the correlation with the average rainfall in the basin. In the case of Lake George, a few years of heavy rainfall and slight evaporation result in a considerable rise of level, and if they were succeeded by a series of dry hot years the lake level would fall gradually until it was dry or until another wet period supervened. It was accordingly found best to correlate the changes in level between the beginning and the end of each year (L') with Sydney rainfall (R), and average sunspot number (S), during the same year, and the following results were obtained :

Correlation between change of level and rainfall; influence of sunspots eliminated : $r=+0 \cdot 35$.

Correlation between change of level and sunspots; influence of rainfall eliminated : $r=+0 \cdot 39$.

The regression equation is :

$\mathrm{L}^{\prime}$ (in inches) $=0.96 \mathrm{R}$ (in inches) $+0.43 \mathrm{~S}$ (Wolf's No.).

The corresponding equation for Lake Victoria, Central Africa, was:

into the basin with little loss, but the subsequent fall in level showed that this could not be the cause, since the destruction of the bush continued while the level of the lake was falling. The nineteen vear periodicity which has been advocated in connexion with Australian weather occurs in the lake levels, though not very definitely, and there is also an eleven-year periodicity connected with the sunspot effect. The two chief maxima in the level, about $\mathrm{I} 82 \mathrm{I}$ and $\mathrm{I} 875$, and the two chief periods when the lake was dry, about 1848 and 1905 , are separated by intervals of 54 to 57 years, and may represent a quasi-periodicity of about 56 years caused by the interference of these two periodicities; but weather cycles are treacherous things, and it would not be safe to base a forecast on them.

C. E. P. B.

\title{
Geological Progress in India.
}

$\mathrm{T}$. is satisfactory to notice that, in spite of financial stress in India, the Government has continued to add to the staff of the Geological Survey, which, with the recruits recently selected, now includes 26 out of the sanctioned 30 officers of the senior grade. The progress of work also during the last few years, since the return to normal duties of those officers who were on active service, has resulted in an approach to completion of many lines of work that had been for some time necessarily left indefinite. Among these the classification of the Tertiary beds of Burma, and their correlation with the Tertiaries of Western India and the standard stratigraphical scale of Europe, are now showing distinct signs of stability.

The untimely death of Mr. E. Vredenburg (NATURE, April I4, p. 505) prevents the completion of the heavy task of summarising the palæontological results, but 